\title{
The Toxic Metal Arsenic Contamination of the Coastal Aquifers in the North Coast of Java, Indonesia
}

\author{
Chrisna Adhi Suryono \\ Marine Science Department, Diponegoro University \\ JI. Prof. Soedarto, SH. Kampus UNDIP Tembalang, Semarang 50275 \\ Email : chrisna_as@yahoo.com
}

\begin{abstract}
Abstrak
Pesatnya perkembangan industri dan aktivitas domestic di daerah pantai utara Jawa mendorong untuk perlunya dilakukan penelitian tentang kemungkinan adanya pencemaran logam Arsen (As) di akifer dangkal kota-kota Jakarta, Semarang dan Surabaya. Sebanyak 30 contoh air dari sumur-sumur yang berasal dari zona pemukiman di daerah pesisir dianalisis kandungan logam As dengan menggunakan teknik Atomic Absorption Spectrophotometer (AAS). Hasil analisis menunjukkan adanya kandungan logam As sebesar $59.65 \mu \mathrm{g} \mathrm{L}^{-1}$ di Jakarta. Rerata dan simpangan baku dari logam As di Jakarta, Semarang and Surabaya adalah $15.47 \pm 18.79,1.25 \pm 2.05$ and $0.59 \pm 0.26 \mathrm{\mu gL}^{-1}$. Terdapat korelasi yang nyata antara logam As dan Fe di airtanah. Dari hasil ini dapat disimpulkan bahwa tingkat kandungan logam As dan Fe di daerah akifer pantai utara Jawa masih berada di bawah ambang yang dipersyaratkan oleh Indonesian Drinking \& Domestic Water Quality Standard for Ground Water and WHO's (World Health Organization) Guideline Valves for Drinking Water, kecuali untuk stasion 5 dan 6 dari Jakarta.
\end{abstract}

Kata kunci: Arsen (As), AAS, akifer pantai

\begin{abstract}
A study was conducted to assess the Arsenic (As) metal contamination of the shallow aquifers in Jakarta, Semarang, and Surabaya city of Java and its relation to the highly developed industrial and domestic activities in the coastal region. Arsen was assayed in the waters of 30 wells throughout the terrestrial cities, in residential zones using Atomic Absorption Spectrophotometer (AAS) technique. Analysis of the As level revealed that high As contents were found primarily in Jakarta, to a maximum of $59.65 \mu \mathrm{g} \mathrm{L}^{-1}$. The mean and standard deviation of As in Jakarta, Semarang and Surabaya were 15.47 $\pm 18.79,1.25 \pm 2.05$ and $0.59 \pm$ $0.26 \mathrm{MgL}^{-1}$, respectively. The groundwater As concentration shows a correlation with $\mathrm{Fe}$ significantly. It was concluded that the levels of As in some investigated 3 Indonesian metropolis cities were below the maximum allowable concentrations of metals recommended by Indonesian Drinking \& Domestic Water Quality Standard for Ground Water and WHO's (World Health Organization)Guideline Values for Drinking Water, except for station 5 and 6 of Jakarta.
\end{abstract}

Keywords: Arsenic (As), AAS, coastal aquifer

\section{INTRODUCTION}

Arsenic (As) is one of the most important toxicant that are widely distributed in nature and occur in the form of inorganic and organic compounds. Exposure to inorganic compounds may occur in a variety of ways through certain industrial effluents, chemical alloys, pesticides, wood preservative agents, combustion of fossil fuels, catalysts, glass, fire retardant, occupational hazards in mining that are anthropogenic and natural sources (Smedly \& Kinniburgh, 2002). Arsenic is known to cause arsenicosis due to its manifestation in drinking water, the 
most common species being arsenate As (V) and arsenite As (III) (WHO, 2007). Arsenic contamination of groundwater has led to a massive epidemic of arsenic poisoning in Bangladesh (Anawar et al., 2003 and Chowdhury, 2004) and neighbouring countries (Berg et al., 2001 and Nickson et al., 2005). It is estimated that approximately 57 million people in Bangladesh (Yu, et al., 2003) and 11 million people in Vietnam (Berg et al., 2001) are drinking groundwater with arsenic concentrations elevated above the World Health Organization's standard of 10 parts per billion (WHO, 1993). This tragedy was occurring as the high arsenic levels present in drinking water. Bangladesh maintains an allowable limit of $50 \mathrm{ppb}$, and the limit in Canada is 25 ppb (Nordstrom, 2002). The arsenic found in Bengale and Canada drinking water is present naturally in the sediment but is released only by humans, primarily from the digging of shallow wells. Similarly unacceptably high arsenic levels are found in shallow-well domestic drinking water in the American Midwest (Kim, et al., 2002).
Recently there has been increasing anxieties concerning arsenic related problems. Occurrence of arsenic contamination has been reported worldwide, for example, Mongolia (Gong et al., 2006), USA (Welch et al., 2000; Kim et al., 2002 and Hudak, 2008;), Bangladesh (Anawar et al., 2003 and Chowdhury, 2004), Taiwan (Chen et al., 1994), Spain (García-Sánchez et al., 2005), et cetera. In Indonesia, no significant As contamination has been reported yet. However, local contaminations in soils, sea and groundwaters with high $\mathrm{As}$ and $\mathrm{Hg}$ levels have been frequently revealed particularly around Buyat Bay mining areas (Khalik and Wulandari, 2004 and KLH, 2004).

Most of the water requirement for metropolis city such as Jakarta, Semarang, Surabaya, is met from surface and groundwater supplies piped in from outside the city limits. However, the case for many cities, a certain proportion of the population, usually the poorest, is forced to rely on dug and shallow wells within the urban area. A study was therefore carried
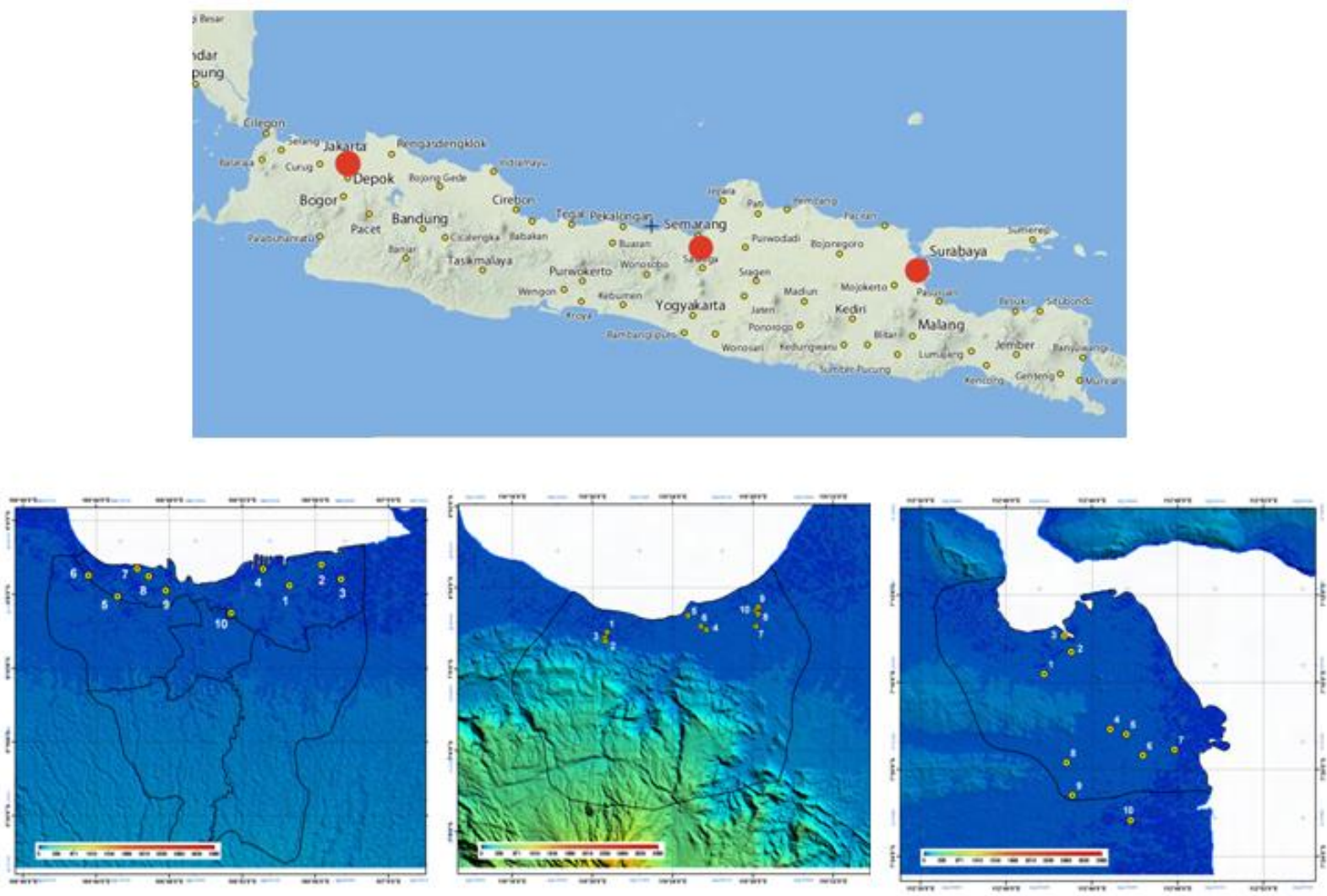

Figure 1. The map of sampling site locations. 
out to gain an idea of the inorganic quality of the water in the wells penetrating the shallow aquifer below the city. This research aim to examine the As content of shallow aquifer in coastal urban areas of Jakarta, Semarang and Surabaya and assess how far they conform with the WHO/Indonesia recommendations for drinking water.

\section{MATERIAL AND METHODS}

\section{Water collections}

A total of thirty samples were collected at each of the stations. Water samples used for As analyses were collected from the residential area shallow aquifer of the north shore of Jakarta, Semarang, and Surabaya metropolis during July-August, 2007 (Fig.1). Shallow aquifer waters are the only sources for drinking water in the study area, however some people uses these waters directly for domestic and drinking and not through the water supplies system. The water samples were collected in $1000 \mathrm{~mL}$ plastic bottles. Then, bottles were properly labeled and tightly sealed. All the water samples were brought to the laboratory for performing water quality tests and heavy metal analyses.

\section{Arsenic metal analysis.}

The water samples were acidified with aliquot of $\mathrm{HNO}_{3}$. About $100 \mathrm{~mL}$ each of the wellmixed acidified water was digested with $5 \mathrm{~mL} \mathrm{HCl}$. The digested samples were then analyzed for As and Fe using atomic absorption spectrometer Perkin Elmer Model 5000 (Kremling at al, 1998). A statistical analysis was conducted among the standard parameters using Linear correlation method. This was performed to know whether any relationship among the parameters existed or not.

\section{Statistical analysis}

The value was used to analyze correlations between As and Fe. ANOVA analysis was made among locations of heavy metal content. All the statistical methods were done using the software Minitab ver.15. Analysis of variance ANOVA was employed after logarithmic conversion when necessary to detect significant differences among mean.

\section{RESULT AND DISCUSSION}

The appearance of arsenic in groundwater and drinking water is a worldwide concern since it has been found that arsenic is one of the most toxic and carcinogenic chemical elements. In the present study As metal concentration was ranging from $0.59 \pm 0.26$ to $15.47 \pm 18.79$ $\mu \mathrm{gL}^{-1}$ respectively in three different cities of Java north shore. The maximum As concentration was observed in Jakarta $\left(59.65 \mathrm{\mu gL}^{-1}\right)$ and minimum was observed in Semarang and Surabaya (undetected). Statistically, there were significant differences among locations, Jakarta, Semarang and Surabaya on quantity of As content. Both Semarang and Surabaya were no significant different on As (Table 1). This condition could be explained that first, arsenic can enter the water supply from natural deposits in the earth or from industrial and agricultural pollution.

It is a natural element used for a variety of purposes within industry and agriculture. It is also a byproduct of copper smelting, mining, and coal burning. Industries in Jakarta were suspected release much more arsenic into the environment every year than those of Semarang and Surabaya. Once released, arsenic remains in the environment for a long time. However, in the present results of this study when it was compare to the previous results in Buyat Bay for Drinking Water (KLH, 2004), it was lower. Because it may be stated that the environmental parameters like salinity, temperature, dissolved oxygen and $\mathrm{pH}$ also have some effect on the accumulation of trace metals.

Among the parameters the salinity played major role in the metal accumulation (Rajan, 1987). Figure 2 showed a positive and significant correlation between As and Fe (Chrisna et al, 2007 in press) in coastal aquifer of Java 
Table 1. Range, mean and standard deviation of As content ( $g(-1)$ in coastal aquifer of Java north shore.

\begin{tabular}{|c|c|c|c|}
\hline \multirow{2}{*}{ Sampling Station } & \multicolumn{3}{|c|}{ As concentration $\left(\mu \mathrm{gL}^{-1}\right)$ in: } \\
\hline & Jakarta & Semarang & Surabaya \\
\hline STl & 7.5 & 0.54 & 0.25 \\
\hline ST2 & 33.65 & 0.13 & 0.39 \\
\hline ST3 & 5.76 & $<0.001$ & 0.40 \\
\hline ST4 & 7.58 & 1.63 & 1.11 \\
\hline ST5 & 21.07 & 0.50 & 0.66 \\
\hline ST6 & 59.65 & 6.21 & 0.89 \\
\hline ST7 & 1.90 & 3.42 & 0.43 \\
\hline ST8 & $<0.001$ & 0.03 & 0.51 \\
\hline ST9 & 16.9 & $<0.001$ & 0.54 \\
\hline STIO & 0.69 & $<0.001$ & 0.76 \\
\hline Range & $0-59.65$ & $0-6.21$ & $0.25-1.11$ \\
\hline Mean and Standard deviation & $15.47 \pm 18.79 \quad a$ & $1.25 \pm 2.05 \mathrm{~b}$ & $0.59 \pm 0.26 \mathrm{k}$ \\
\hline
\end{tabular}

Note: The difference of alphabet showed significant difference

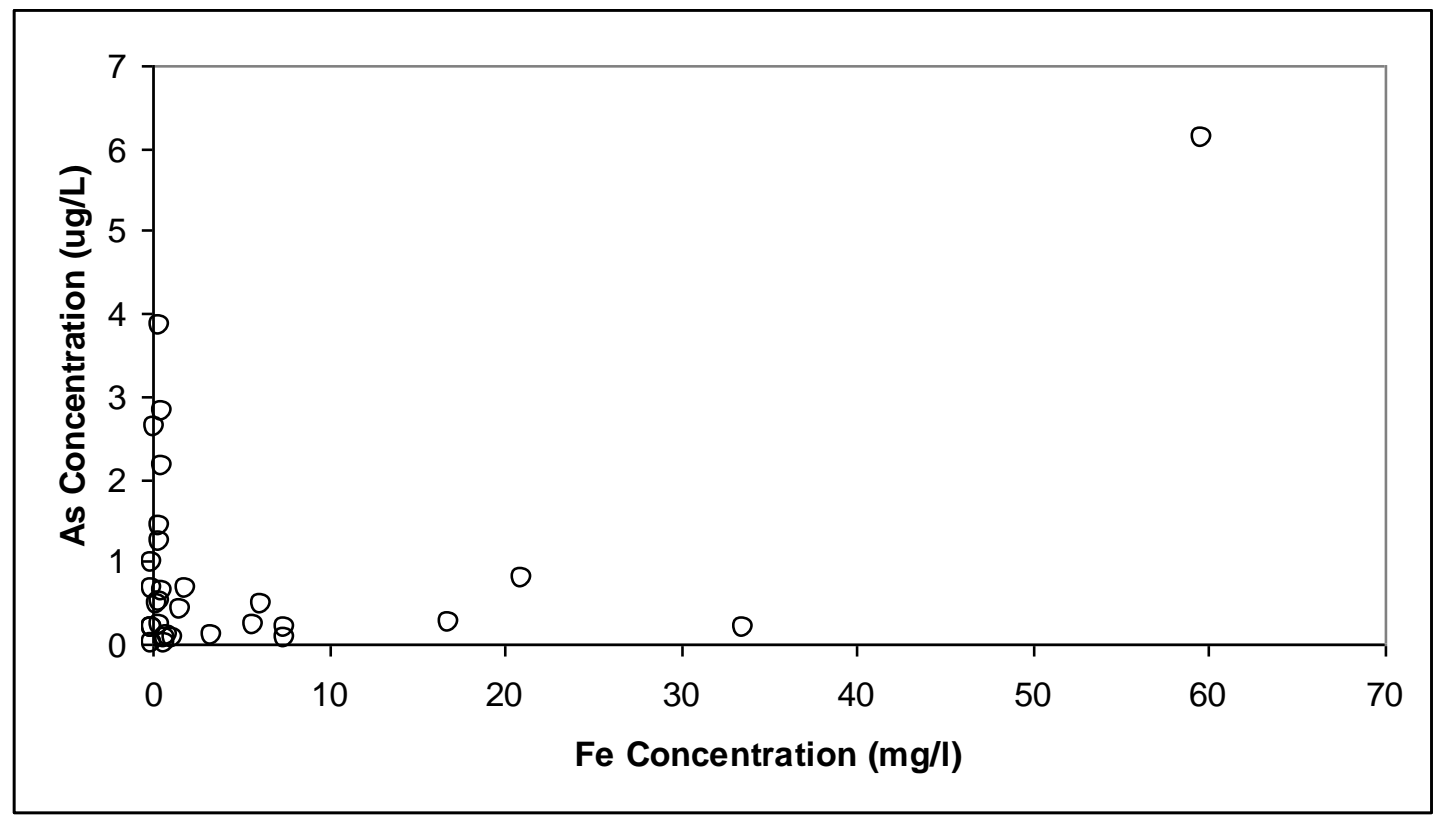

Figure 2. Relation of Arsenic and iron in coastal aquifer $(p=0.005)$

north shore. As consentrations correlate well with concentration of dissolved Fe. It means that the higher the dissolved Fe, the arsenic concentration increase. Many authors have reported the correlations between As and $\mathrm{Fe}$ in a variety of environments, often with the explanation that As adsorbs onto $\mathrm{Fe}$ (hydroxides) under oxidizing conditions and is then released when the (hydroxide) undergoes reductive dissolution (Zheng et al., 2004; Mirlean et al., 2006;). Bhatacharya et al. (1997) reported that arsenic is released when arsenic-rich iron oxyhydroxides are produced in anoxic groundwater. In addition, Nickson et al. (1998) stated that arsenic derived from the oxidation of arsenic-rich pyrite in the aquifer sediments as atmospheric oxygen invades the aquifer in response to a lowering of the water level by abstraction. Previous investigations in Bangladesh have also suggested that arsenic may enter the aquifer associated with iron oxide coatings on the sediment grains and when conditions become reduced, the arsenic is released to the groundwater together with 
$\mathrm{Fe}^{2+}$ (McArthur et al., 2001; Smedly and Kinniburgh, 2002). Bone et al. (2006) reported that strong correlation between As and Fe provides solid evidence that As is linked to the Fe redox cycle.

\section{CONCLUSION}

This experiment has shown that the entire water sample meets the limits of WHO and Indonesian Drinking \& Domestic Water Quality Standard for Ground Water, except for station 5 . This study confirmed a significant relationship between the arsenic concentration and iron concentration in coastal aquifer of Java north shore. I means that coastal aquifer of Java north shore is not polluted. With regard to mitigation, shallow aquifer with low concentrations of arsenic in water which are continuing to be used need to be monitored over time by authorities concerned to ensure that concentrations of arsenic in water of these shallow aquifer remain at an acceptable level over time.

\section{REFERENCES}

Anawar, H.M., J. Akai, K. Komaki, H. Terao, T. Yoshioka, T. Ishizuka, S. Safiullah, and K. Kato. 2003. Geochemical occurrence of arsenic in groundwater of Bangladesh: Sources and mobilization processes. J. Geochem. Explor. 77:109-131.

Anonymous. 1997. Water quality. Ohio Department of Natural Resources. Division of Water.3 p.

Anonymous. 2003. Arsenic and Drinking Water from Private Wells. NSF International.

Anonymous. 2008. Key to Metals AG. All Rights Reserved.

Bautista, M.A. and A.K. Pradhan. 1995. Iron and Nickel Abundances in $\mathrm{H} \sim \|$ Regions and Supernova Remnants.

Berg, M., Tran, H.C., Nguyen, T.C., Pham, H.V., Schertenleib, R., Giger, W., 2001. Arsenic contamination of groundwater and drinking water in Vietnam: a human health threat. Environ. Sci. Technol. 35, 2621-2626.

Bhattacharya, P., D. Chatterjee, and G. Jacks. 1997. Occurrence of arsenic- contaminated groundwater in alluvial aquifers from delta plains, eastern India: Options for safe drinking water supply. Water Resour. Dev. 13:79-92.

Bone, E.S., M.E. Gonneea, and M.A. Charette. 2006. Cycling of Arsenic in Coastal Aquifer. Environ. Sci. Technol. 40:3273-3278

Chen, S.L., S.R. Dzeng, M.H. Yang, K.H. Chiu, G.M. Shieh, and C.M. Wai. 1994. Arsenic species in groundwaters of the blackfoot disease area, Taiwan. Environ. Sci. Technol. 28:877-881.

Chowdhury, A. M. R. 2004. Arsenic crisis in Bangladesh. Sci. Am. 291:86-91.

Chrisna A. S, Baskoro, R, Agus, S and Tyas, S. B., 2007. Physico-chemical Characteristics and Heavy Metal Contents in Shallow Groundwater of Semarang Coastal Region. (in press). Ilmu Kelautan (12) 3:

García-Sánchez, A. , A. Moyano and P. Mayorga. 2005. High arsenic contents in groundwater of central Spain. Environ. Geol. Vol. 47(6):847854

Gong, Z., X. Lu, C. Watt, B. Wen, B. He, J. Mumford, Z. Ning, Y. Xia and X. C. Le. 2006. Speciation analysis of arsenic in groundwater from Inner Mongolia with an emphasis on acid-leachable particulate arsenic. Analytica Chimica Acta Vol. 555 (1):181-187

Hudak, P.F. 2008. Distribution of arsenic concentrations in groundwater of the Seymour Aquifer, Texas, USA. Int. J. of Environ. Health Research, Vol. 18 (1): $79-82$

Khalik, A. and F. Wulandari. 2004. Buyat Bay tests show high mercury levels. Jakarta Post July 30, 2004

Kim, M. J., J. Nriagu, and S. Haack. 2002. Arsenic species and chemistry in groundwater of southeast Michigan. Environ. Pollut. 120:379-390.

KLH .2004. REPORT. Environmental Quality Assessment of Buyat Bay and Totok Bay. Kementerian Lingkungan Hidup. $41 \mathrm{p}$

Kremling, K., Andreae, M.O., Brugmann, L., van den Berg, $C, M, G$., Prange, A., Schirmacher., Koroleff, F., and Kuss, J., 1998. Determination of Trace Elemens in Method of Seawater Analysis. Wiley-Vch. Toronto. $254-364$ pp 
McArthur, J.M., Ravenscroft, P., Safiulla, S., Thirlwall, M.F., 2001. Arsenic in groundwater: testing pollution mechanisms for sedimentary aquifers in Bangladesh. Water Resour. Res. 37, 109-117.

Mirlean, N.; V. E. Andrus, P. Baisch, G.Griep, and M.R.Casartelli. 2006. Arsenic pollution in Patos Lagoon estuarine sediments, Brazil. Mar. Pollut. Bull. Vol. 46: 1480-1484.

Nickson, R., J. McArthur, W. Burgess, K.M. Ahmed, P. Ravenscroft and $M$. Rahman. 1998. Arsenic poisoning of Bangladesh groundwater. Nature Vol.395: 338

Nickson, R.T., J.M. McArthur, B. Shrestha, T.O. Kyaw-Myint, and D. Lowry. 2005. Arsenic and other drinking water quality issues, Muzaffargarh District, Pakistan. Applied Geochemistry 20: 55-68

Nordstrom, D.K. 2002. Worldwide Occurrences of Arsenic in Ground Water. Science Vol.296: 2143-2144

Rajan, A , 1987. Studes onDonax cuneatus (Linnaeus) (Mollusca: Bivalvia: Donacidae) from Polto Novo waters. PhD Thesis, Annarnalai University. In Shanmugam, A., C. Palpandi and K.
Kesavan. 2007. Bioaccumulation of Some Trace Metals (Mg, Fe, $\mathrm{Zn}, \mathrm{Cu}$ ) from Begger's Bowl Cymbium melo (Solander, 1786) (A Marine Neogastropod). Research J. of Environ. Sci. 1 (4): 191-195

Smedley, P.L. andDG Kinniburgh, 2002. Areview of the source, behaviour and distribution of arsenic in natural waters. Applied Geochem., 17: 51 7568.

Welch, A.H., D.B.Westjohn, D.R. Helsel and R.B. Wanty. 2000. Arsenic in ground water of the United States: occurrence and geochemistry. Ground Water. Vol. 38 (4):589-604.

WHO, 1993. Guidelines for Drinking-water Quality, 2nd ed., vol. 1. Recommendations, Geneva.

WHO, 2007. Arsenic in Drinking Water .

Yu, W.H., Harvey, C.M., Harvey, C.F., 2003. Arsenic in groundwater in Bangladesh: a

Zheng, Y.; M. Stute, A. van Geen, I. Gavrieli, $R$ Dhar, H.J. Simpson, P. Schlosser, M.K.Ahmed. 2004. Redox control of Arsenic mobilization in Bangladesh groundwater. Appl. Geochem. Vol.19: 201-214. 